P̈roc. Estonian Acad. Sci. Geol., 1994, 43, 4, 165-176

\title{
ON MINERALOGY OF THE PORPHYRACEOUS POTASSIUM GRANITES OF SMALL MASSIFS IN THE NORTHERN ESTONIAN BASEMENT
}

\author{
Vello KLEINa, Mare KONSA ${ }^{\mathrm{b}}$, and Mati NIINa
}

a Eesti Geoloogiakeskus (Geological Survey of Estonia), Pikk 67, EE-0001 Tallinn, Eesti (Estonia)

b Eesti Teaduste Akadeemia Geoloogia Instituut (Institute of Geology, Estonian Academy of Sciences), Estonia pst. 7, EE-0105 Tallinn, Eesti (Estonia)

Presented by V. Puura

Received March 21, 1994; accepted May 20, 1994

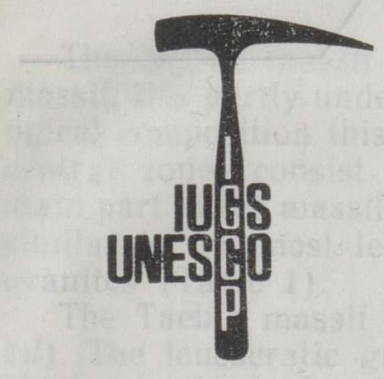

\section{Project 275 \\ BALTIC SHIELD} and

Project 315

RAPAKIVI GRANITES

\begin{abstract}
The content of porphyraceous potassium granites and the chemical composition of these minerals bear witness to a remarkable heterogeneity of small plutons and also to the process of their evolution through many stages. An attempt was made to define the conditions of the formation of potassium granites and the possible cooling rate of plutons. Basing on the zircon types it is possible to distinguish early- and late-magmatic stages in the massifs.
\end{abstract}

Key words: mineralogy, potassium granites, Precambrian. Estonia.

\section{INTRODUCTION}

Presently five small early platform massifs of porphyraceous granites are known in North Estonia. These are Märjamaa, Naissaare, Neeme, Taebla, and Ereda (Soesoo \& Niin, 1992; Fig. 1). They are genetically and by age related to Wiborg and Riga rapakivi plutons. According to the geophysical data, the massifs of potassium granites of North Estonia occur as intrusions sharply transecting the surrounding lower Proterozoic metamorphic rocks. We compared these massifs with the small ones of South Finland (Кууспалу, 1975).

The biggest, Märjamaa massif $(40 \times 25 \mathrm{~km})$, has an asymmetrically rounded form (Fig. $1 a$ ) and zonal composition. The central part of the pluton consists of relatively melanocratic rock (Table 1) whose mineralogical and chemical composition is close to granodiorite. It was probably formed at the earliest stage of the intrusion process (representing the first phase of crystallization). The periphery of the massif is made up of more leucocratic granites (second phase) with increased content of microcline and decreased content of biotite. The oval-shaped northwestern part 
of the massif, forming the so-called gravity minimum of Kloostri, differs substantially from its main part. Here the most leucocratic granites were formed at the last stage of the intrusion (third phase). Unlike the main rocks of the massif, the granites of the third phase do not contain hornblende, but the appearance of muscovite and fluorite is typical, and so is the sporadic trachytoid structure.

The northern part of the Naissaare massif $(35 \times 25 \mathrm{~km}$, Fig. $1 b)$ lies under the Gulf of Finland. The most melanocratic granites (first phase) form the periphery of the massif. The central part of the pluton is composed of leucocratic granites (second phase), which have some similarities with the third phase of the Märjamáa intrusion.

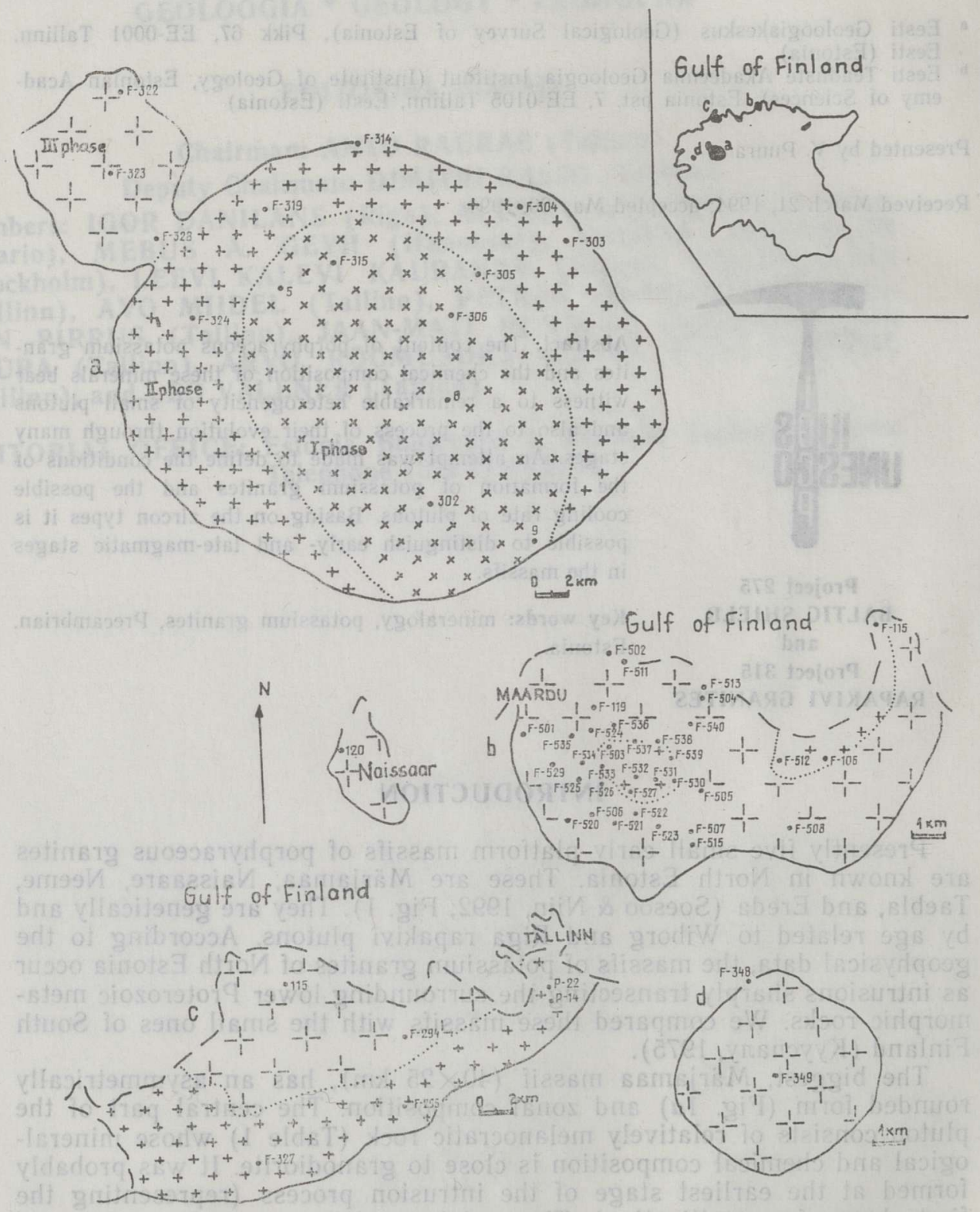

Fig. 1. Location and size of the studied porphyraceous potassium granite massifs. Dots with numbers designate drill holes. $a$, Märjamaa; $b$, Neeme; $c$, Naissaare; $d$, Taebla. 
Mineral composition of porphyraceous potassium granites

(average modal composition, vol. \%)

\begin{tabular}{|c|c|c|c|c|c|c|c|c|}
\hline \multirow{3}{*}{ Minerals } & \multicolumn{8}{|c|}{ Plutons/phases } \\
\hline & \multicolumn{3}{|c|}{ Märjamaa } & \multicolumn{2}{|c|}{ Neeme } & \multirow{2}{*}{$\begin{array}{l}\text { Nais- } \\
\text { saare }\end{array}$} & \multirow{2}{*}{ Taebla } & \multirow[b]{2}{*}{ Aplites } \\
\hline & I & II & III & I & II & & & \\
\hline Quartz & 25.8 & 25.6 & 27.8 & 34.8 & 28.3 & 28.3 & 28.0 & 31.3 \\
\hline Microcline & 23.1 & 49.0 & 34.0 & 23.1 & 38.6 & 31.0 & 39.3 & 31.6 \\
\hline Plagioclase & 37.8 & 17.1 & 34.3 & 33.4 & 28.1 & 32.2 & 25.0 & 31.6 \\
\hline Biotite & 7.0 & 3.4 & 2.1 & 7.8 & 3.9 & 6.6 & 5.6 & 4.8 \\
\hline Muscovite & - & + & + & 0.1 & 0.3 & - & 1.0 & 0.2 \\
\hline Hornblende & 2.9 & 4.0 & - & 0.2 & - & 1.7 & - & - \\
\hline Opaques & 1.5 & 0.7 & 1.1 & 0.3 & 0.6 & + & 0.3 & 0.5 \\
\hline Accessories & 1.9 & 0.2 & 0.7 & 0.3 & 0.2 & 0.2 & 0.8 & + \\
\hline Total & 100 & 100 & 100 & 100 & 100 & 100 & 100 & 100 \\
\hline
\end{tabular}

+ a few grains; - not found.

The Neeme massif (diameter c. $15 \mathrm{~km}$, Fig. 1c), like the Naissaare massif, lies partly under the Gulf of Finland. By its chemical and mineralogical composition this pluton can be divided into two phases. Two small central zones consist of more melanocratic granites (first phase), the main part of the massif is composed of leucocratic granites (second phase) similar to the most leucocratic varieties of Märjamaa and Naissaare granites (Table 1).

The Taebla massif is the smallest with a diameter of $6-7 \mathrm{~km}$ (Fig. 1d). The leucocratic granites of the pluton are rather homogeneous and similar to the rocks of the third phase of the Märjamaa massif and the second phases of the Neeme and Naissaare massifs.

The Ereda massif $(15 \times 5 \mathrm{~km})$, oval in form, is composed of homogeneous porphyraceous granites. As the material available from two drill cores is limited, it is complicated to correlate these rocks with others. However, some similarities have been observed between the Ereda granites and more leucocratic types of the Märjamaa, Neeme, and Naissaare granites.

\section{METHODS}

Geological characterization of the potassium granites was compiled and examination of mineralogical composition of the rocks was carried out by Mati Niin. Heavy mineral fractionation was studied and the description of accessory minerals was presented by Mare Konsa. The minerals were separated and the analyses interpreted by Vello Klein.

Heavy mineral grains (accessories and opaques) were studied by means of immersion-microscopic analysis. The number of grains counted from each sample was 500. This method is less exact than the crystallooptical method (Вийдинг, 1976), but it enables to operate with rather small samples and is well applicable for the comparison of similar rock types (Клейн \& Конса, 1986).

Wet chemical analyses of minerals were carried out at the Chemical Laboratory of the Geological Survey of Estonia by Mare Kalkun and Silvi Hinn. 


\section{MINERAL COMPOSITION}

Quartz, plagioclase, microcline, and biotite are the dominant minerals in porphyraceous potassium granites of all petrographic varieties (Table 1). Macroscopically separated distinct phases of massifs display differences in the content of these minerals; some phases include in addition hornblende and muscovite. Hornblende is rather frequent in the Märjamaa granites of phases I and II and in the Naissaare granites, but less frequent in the Neeme granites of phase I.

Muscovite characterizes usually the latest phase of granite crystallization or occurs as a secondary mineral. The content of the opaques and accessories is rather small exceeding the average of $1 \%$ only in phase I of the Märjamaa massif. A characterization of whole-rock minerals can be found in an earlier publication (Soesoo \& Niin, 1992).

According to microcline/quartz/plagioclase ratios the composition of phase I of the Märjamaa granites and the Neeme granites is close to that of granodiorite (Fig. 2).

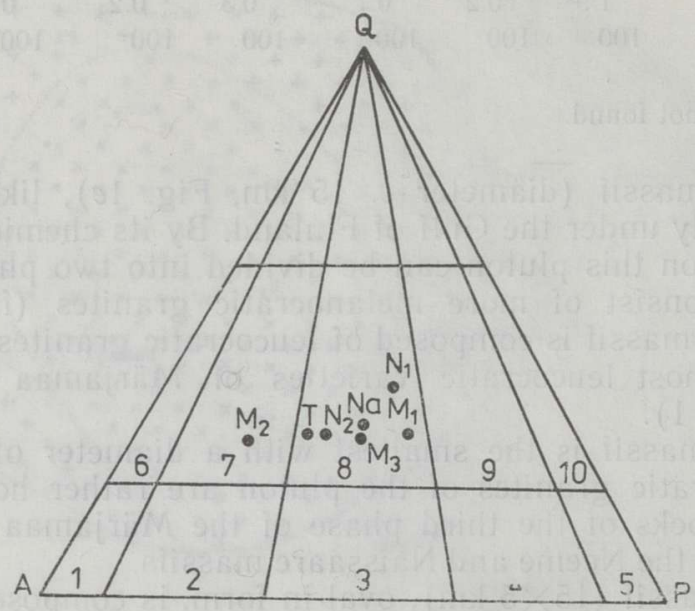

Fig. 2. Average modal composition of the granites shown in the APQ diagram of Streckeisen (1974).

$M_{1}, M_{2}, M_{3}$, Märjamaa; $N_{1}, N_{2}$, Neeme; $N a$, Naissaare; T, Taebla granites.

\section{CHEMICAL COMPOSITION OF MINERALS}

The chemical composition of rock-forming minerals was examined by wet chemical analysis of 13 biotite and 3 hornblende samples (Tables 2 and 3). The general aspects of the evolution of the granitic magma in the studied massifs were discussed by Kirs and Soesoo on a more representative material earlier (Кирс et al., 1990; Soesoo, 1993). Their discussion gives a wider background for the interpretation of the chemical analyses of the selected samples carried out for getting approximate estimates of mineral crystallization conditions and the speed of the processes involved.

The analyses revealed that the iron and titanium contents of the biotite and hornblende of the massifs do not correlate with the corresponding values of the surrounding rocks (Fig. $3 a-3 d$ ), and may thus, at least to some extent, be related to the pressure-temperature (PT) conditions of rock formation. The $\mathrm{Fe}$ content of biotite varies from the average of $50 \mathrm{~mol} \%$ for the Märjamaa massif to $82-87 \mathrm{~mol} \%$ for the Naissaare and 


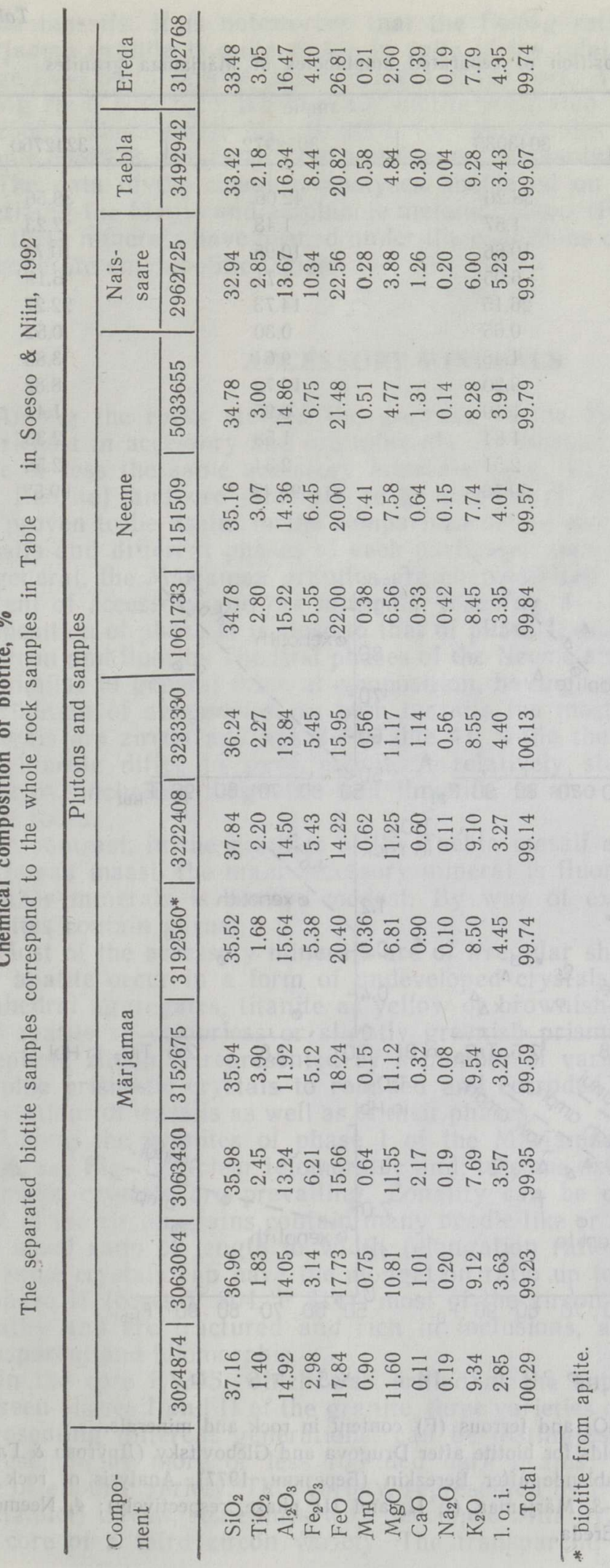


Chemical composition of separated amphiboles of Märjamaa granites

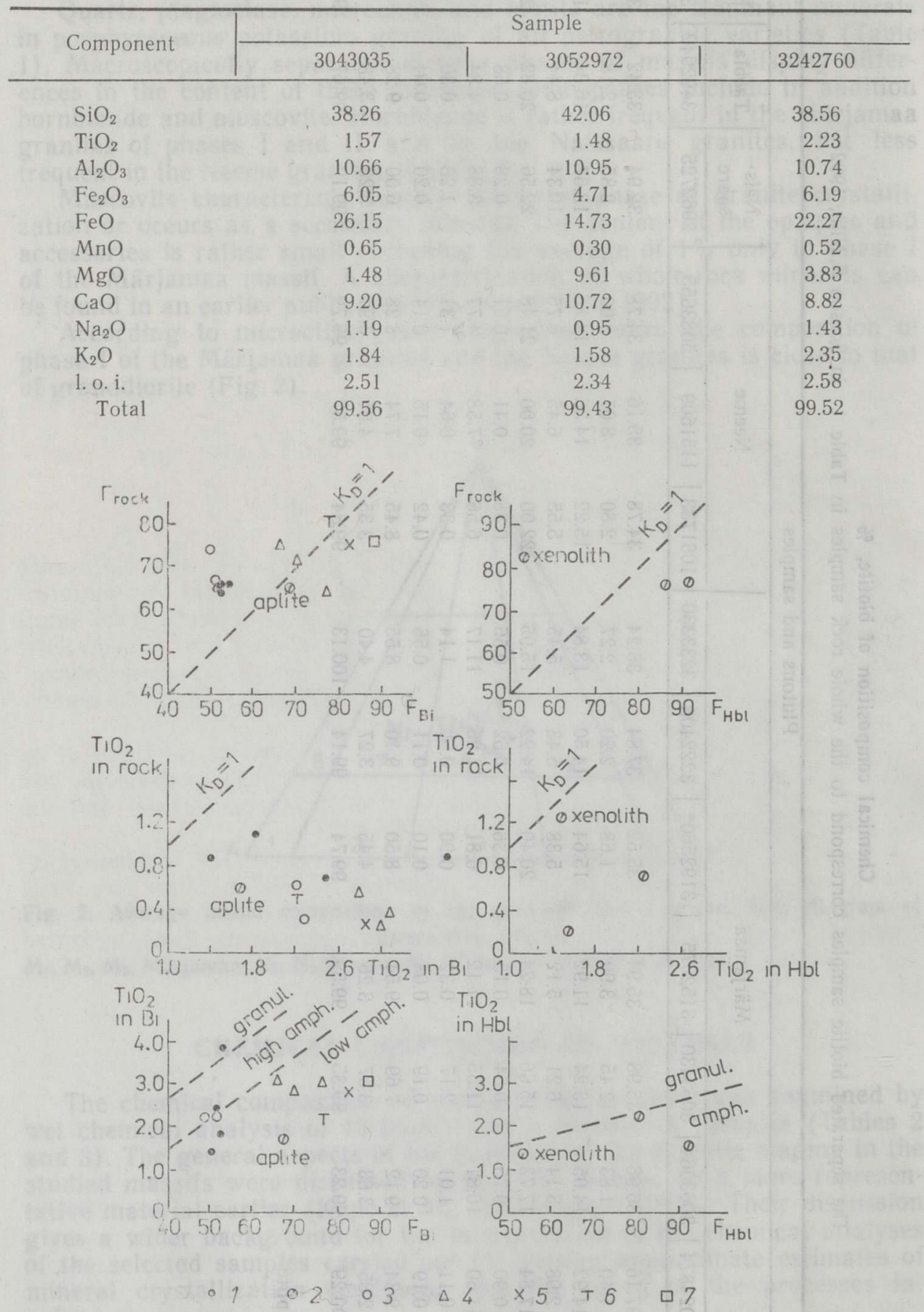

Fig. 3. $\mathrm{TiO}_{2}$ and ferrous $(\mathrm{F})$ content in rock and minerals.

Granulite-amphibolite fields for biotite after Drugova and Glebovitsky (Другова \& Глебовицкий, 1965), for hornblende after Berezkin (Березкин, 1977). Analysis of rock and minerals of massifs: $1-3$, Märjamaa (I, II, and III phase, respectively); 4 , Neeme; 5 , Naissaare; 6, Taebla, 7, Ereda. 
Ereda massifs. It is noteworthy that the $\mathrm{Fe} / \mathrm{Mg}$ ratio of the biotites of Märjamaa granite is quite stable in spite of the relatively wide variation range from 64 to $74 \%$ of the Fe content of the rock. A significantly higher $\mathrm{Fe} / \mathrm{Mg}$ ratio was recorded only for biotite separated from aplite (sample 3192560). The highest $\mathrm{Mg}$ content for amphiboles was recorded for sample 3052972 , separated from a melanocratic xenolith.

The data of the chemical analyses, displayed on the diagrams characterizing the biotite and amphibole metamorphism (Fig. $3 e-3 f$ ), indicate that these minerals have formed under the conditions corresponding to low to moderate amphibolitic facies.

\section{ACCESSORY MINERALS}

Among the rocks studied the granites of the Märjamaa massif are the richest in accessory and ore minerals. As most of the massifs contain more or less the same accessory minerals (e. g., titanite, zircon, apatite, and fluorite) and ore minerals (e.g. magnetite), their relative content has proven to be useful in the comparison of the composition of different massifs and different phases of each particular massif (Tables 1 and 4). In general, the Märjama granites are characterized by a relatively high content of accessory and ore minerals reaching $1-3 \%$ (Table 1$)$. The composition of phase II is close to that of phase I, differing in the content of zircon and fluorite. The first phases of the Neeme and Naissaare massifs are similar in general mineral composition, having only slightly different distribution of accessories. In both massifs the most common accessory minerals are zircon and apatite (Table 4), while the contents of titanite and fluorite differ to some extent. A relatively stable content of ore minerals, including magnetite and ilmenite, is also characteristic of all these rocks.

In contrast, in the granites of the Taebla massif and phase III of the Märjamaa massif the main accessory mineral is fluorite, and the content of other minerals is always modest. By way of exception, the Taebla granites contain garnet.

Most of the accessory minerals are of irregular shape. Pyrite, titanite, and apatite occur in a form of undeveloped crystals: pyrite as cubic or octahedral aggregates, titanite as yellow or brownish-yellow octahedrons, and apatite as colourless or slightly greenish prismatic crystals. As an exception, zircon is represented by a number of varieties, from the idiomorphic prismatic crystals to rounded and corroded grains, allowing of correlations of massifs as well as of their phases.

Among the granites of phase I of the Märjamaa massif (drill core F 306, see Fig. 1a), clear idiomorphic and, to some extent, panidiomorphic prismatic crystals are prevailing. Zonality can be observed rarely and most of the zircon grains contain many needle-like or irregular inclusions. The usual ratio of length to width (elongation ratio) of crystals is $2: 1$, but some crystals can have the elongation ratio up to $6: 1$. In the granite of phase II (cores F 304, F 314), most of the zircon crystals show clear zonality and are fractured and rich in inclusions, and they are mostly transparent and idiomorphic.

In the core F 305, which was drilled at the supposed contact zone between phases I and II of the granite, three varieties of zircon, most likely representing different generations, can be distinguished. One variety is represented by more or less rounded dark grains, mostly forming the core of another variety. This variety, represented by translucent or opaque (metamict) zircon, sometimes with developed zonality, in turn often forms the core of a third zircon variety. The transparent, clearly idiomorphic 
grains of the last zircon variety occur also separately, often with welldeveloped zonality.

The zircon from Märjamaa aplite-granite has also quite characteristic features (core F 319 , see Pl. I, figs. 5-7). The grains are mostly idiomorphic, but are not particularly clean and transparent. Zonality, fracturing, and inclusions can be observed. Twinned crystals similar to those formed by an intergrowth of two idiomorphic crystals occur (P1. I, fig. 7). In addition to the idiomorphic crystals, panidiomorphic crystals with a new overgrowth layer visible in some of the crystals are present.

Table 4

Percentage of opaques and accessories in granites

The content of minerals in a sample was summed to $100 \%$

\begin{tabular}{|c|c|c|c|c|c|c|c|c|}
\hline $\begin{array}{l}\text { Pluton, } \\
\text { sample }\end{array}$ & $\begin{array}{l}\text { Pyr }+ \\
\text { Pyrr }\end{array}$ & $\begin{array}{l}\mathrm{Ilm}+ \\
\mathrm{Mt}\end{array}$ & $\begin{array}{l}\text { Sph } \\
\text { (Ti) }\end{array}$ & $\mathrm{Zr}$ & Ort & Ap & $\mathrm{F} 1$ & Others \\
\hline \multicolumn{9}{|l|}{ Märjamaa } \\
\hline 3063064 & 0.5 & 31.4 & 34.6 & 2.6 & 0.3 & 28.0 & 2.8 & \\
\hline 3063430 & 1.3 & 33.0 & 31.2 & 4.4 & 0.3 & 28.0 & 1.8 & \\
\hline 3052780 & - & 37.8 & 4.5 & 31.1 & 2.2 & 24.4 & - & \\
\hline 3052972 & - & 52.3 & 9.1 & 27.3 & 3.4 & 7.9 & - & \\
\hline 3032833 & 2.6 & 31.1 & 10.4 & 14.3 & - & 39.0 & 2.6 & \\
\hline 3033338 & - & 41.1 & 19.6 & 12.7 & - & 25.4 & 1.2 & $10=21$ \\
\hline 3042288 & - & 25.0 & 11.1 & 47.2 & 2.8 & 5.6 & 8.3 & B seminit \\
\hline 3042790 & - & 25.7 & 4.4 & 18.1 & 1.1 & 1.1 & 49.7 & $19 \mathrm{fll}$ \\
\hline 3043035 & - & 34.4 & 9.8 & 29.5 & 3.3 & - & 23.0 & \\
\hline $3142676^{*}$ & 3.1 & 62.5 & 1.6 & 28.1 & - & 1.6 & 3.1 & $\begin{array}{ll}\text { Turm } & 1.8\end{array}$ \\
\hline $3192560 * *$ & 7.3 & 7.3 & 1.8 & 7.3 & - & 36.3 & - & Leuk \\
\hline 3222408 & 4.7 & 53.1 & 0.5 & 2.6 & - & 8.3 & 30.8 & \\
\hline 3233330 & 4.6 & 56.7 & 1.1 & 3.7 & 2.3 & 7.6 & 23.6 & Leuk \\
\hline \multicolumn{9}{|l|}{ Neeme } \\
\hline 1061733 & - & 3.0 & 54.6 & 10.2 & 0.8 & 28.2 & 3.2 & silf \\
\hline 1151509 & - & 42.3 & 8.7 & 27.9 & - & 13.8 & 7.3 & \\
\hline \multicolumn{9}{|l|}{ Naissaare } \\
\hline 2962725 & - & 17.8 & 4.4 & 13.4 & 1.0 & 23.3 & 40.1 & \\
\hline 2962820 & BT & 26.1 & 3.2 & 19.3 & 2.3 & 11.5 & 34.4 & Ep \\
\hline \multicolumn{9}{|l|}{ Taebla } \\
\hline 3483550 & - & 8.7 & 0.9 & 3.5 & - & 0.9 & 78.2 & Ep \\
\hline & & & & & & & & $\begin{array}{l}\mathrm{Gr} \\
\text { Leuk }\end{array}$ \\
\hline 3492942 & 1.2 & 18.3 & 8.3 & 4.1 & 0.6 & 2.4 & 61.5 & Ep \\
\hline tyonas & & & & & & & & $\mathrm{Gr}$ \\
\hline
\end{tabular}

* K-granite in contact with surrounding rock; ** aplite; + a few grains; - not found. 


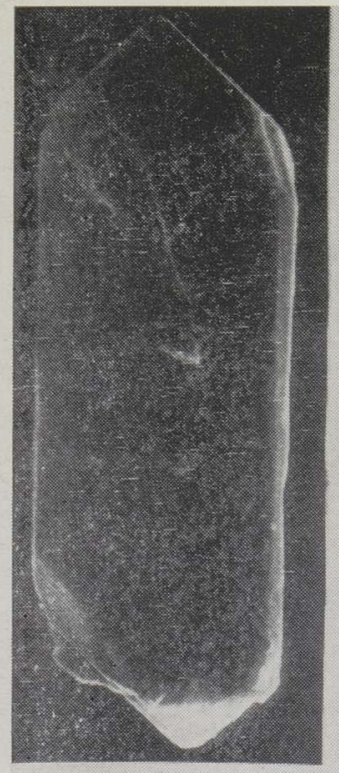

1

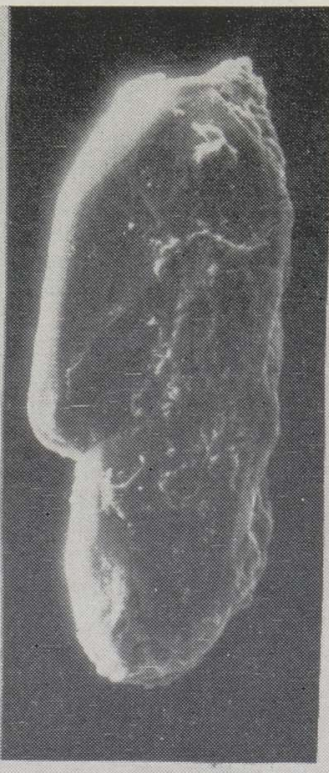

2

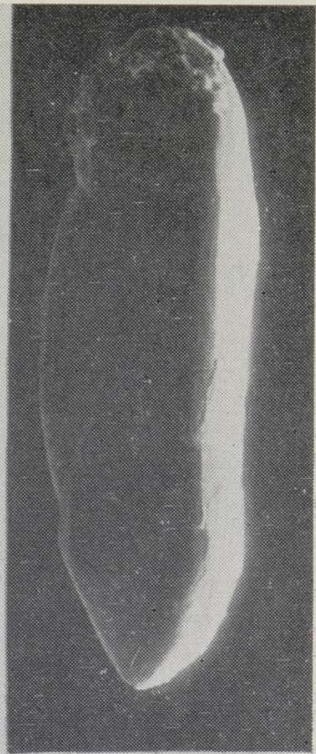

3

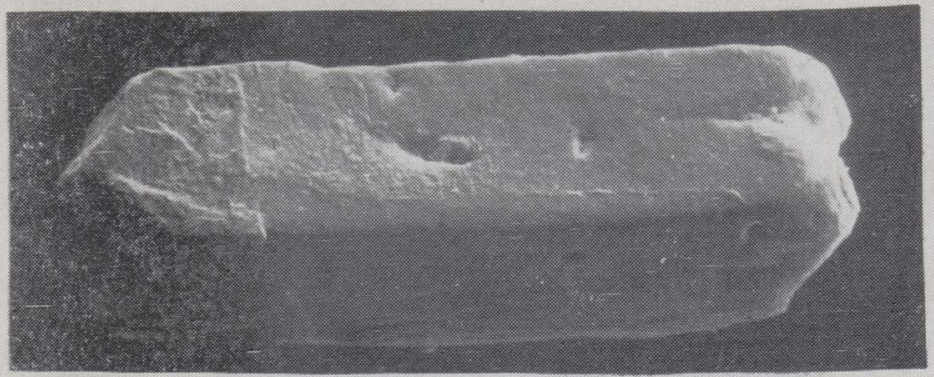

5

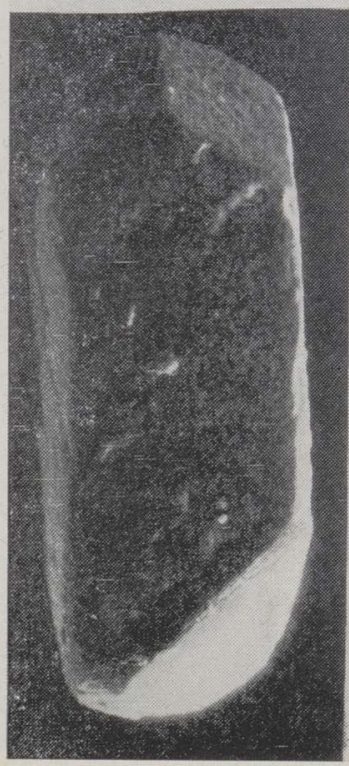

6

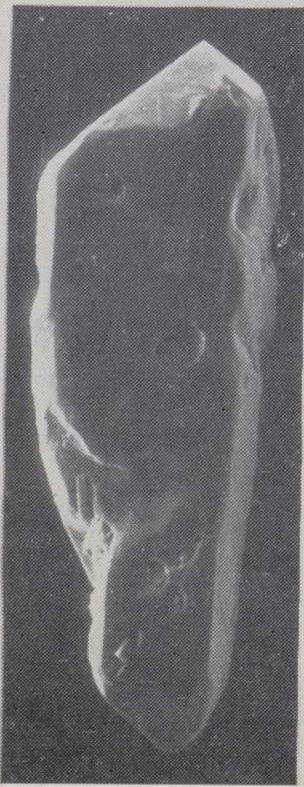

4

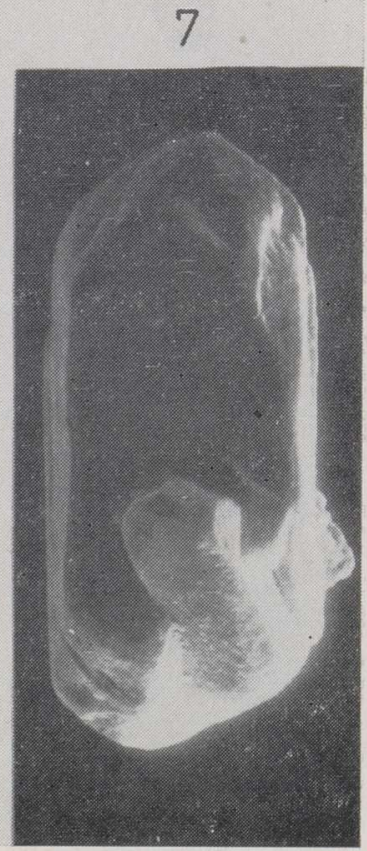

SEM microphotographs of zircon crystals from Märjamaa porphyraceous K-granite Figs. 1-4, drill core F 323; figs. $5-7$, drill core F 319 . Photo Ursula Moldov. 
PLATE II

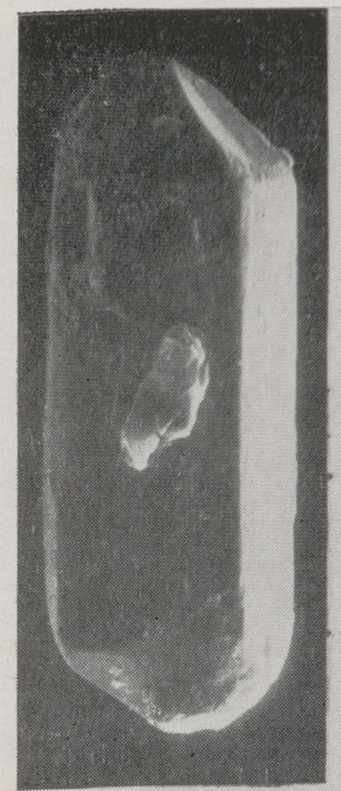

1

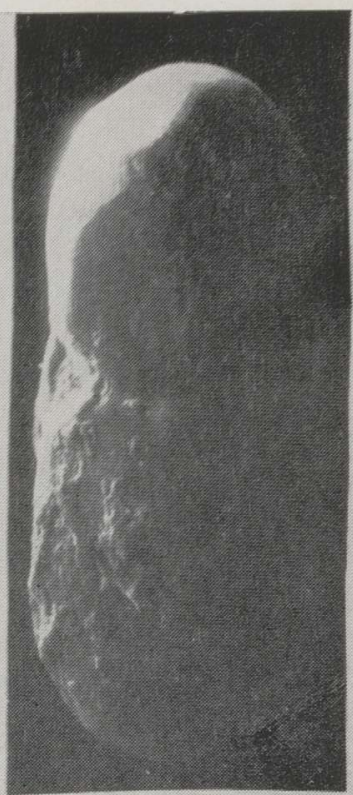

2

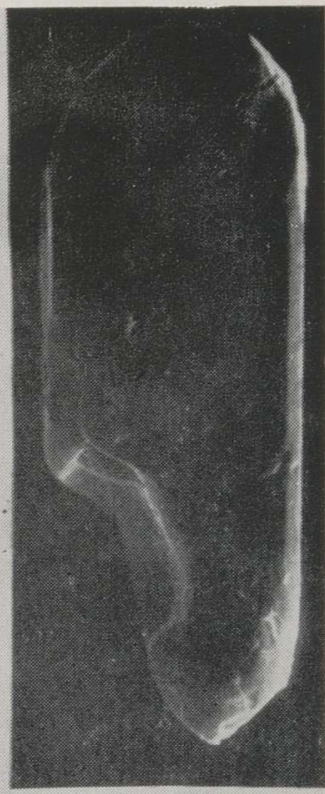

3

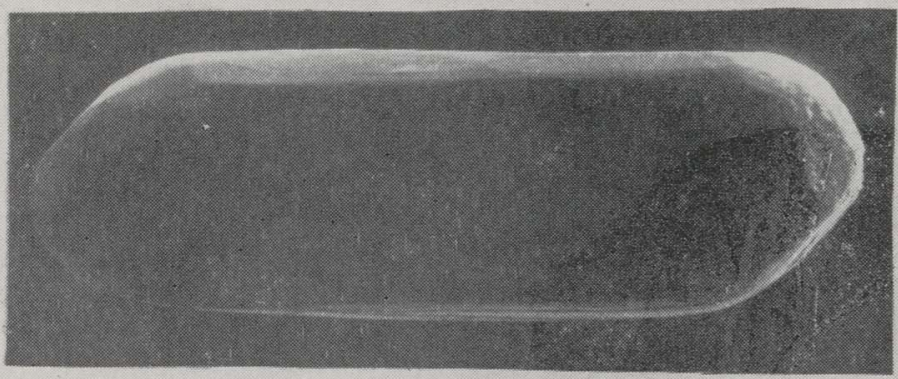

5

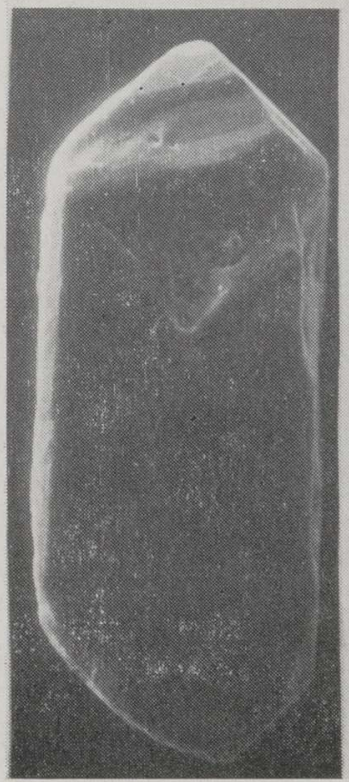

6

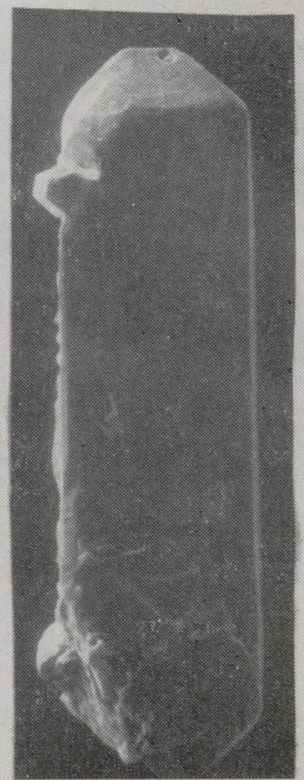

7

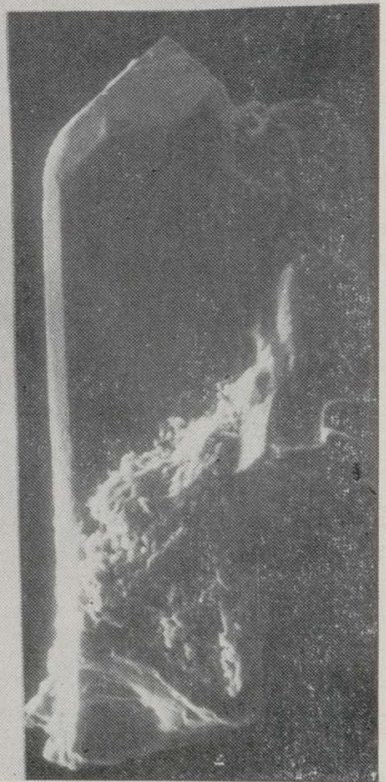
SEM microphotographs of zircon crystals from Taebla porphyraceous K-granite
massif, $\times 1000$.

Figs. 1-4, drill core F 349; figs. $5-7$, drill core F 348 . Photo Ursula Moldov. 
In the leucocratic phase III o: the Märjamaa granite (F 322, F 323), mostly clean idiomorphic zircon crystals occur (Pl. I, figs. $1-4$ ). These crystals contain a few inclusions, but lack fracturing and zonality. The panidiomorphic grains occurring mostly as separate crystals, sometimes also as cores of another variety, are darker, less clean, and often fractured. Many zircon grains bear traces of corrosion.

Zircon grains in the small Taebla massif (F 348, F 349, see Pl. II) resemble in general terms the above-described varieties, showing even a greater extent of variation. Zonality and fracturing can be observed both in idiomorphic and panidiomorphic crystals. Often, idiomorphic zircon crystals envelope a darker and more metamict panidiomorphic crystal, which can contain in turn an opaque core. Also grains with traces of corrosion and epitaxial crystals can be observed (Pl. II, fig. 7). However, most of the zircon grains originating near the contact zone of the massif (Fig. 1d, core F 348) show quite distinct features. In these grains, inclusions are not present or not visible, the grain shape varies from regular to irregular, and sometimes aggregates of grains occur.

The zircon grains from the Neeme (Fig. 1b, F 106 and F 115) and Naissaare (Fig. 1c, F 296) massifs are very similar to each other. Idiomorphic and quite regular-shaped crystals, with the elongation coefficient from 2 to 4 , are prevailing. Zircon grains are relatively big and zonality is common, while corrosion of the grains is uncommon. The described zircon grains resemble those of phases I and II of the Märjamaa massif.

\section{DISCUSSION}

Investigations of small plutons of porphyraceous granites in recent years have shown them to consist of two or more magmatic phases of rocks, analogical to typical rapakivi massifs. Earlier petrochemical and partially mineralogical findings (Soesoo \& Niin, 1992) reveal substantial similarities between potassium granites of small plutons and large rapakivi massifs (Wiborg, Salmi, Korosten). At the same time it is possible that the first, most melanocratic phase of rocks seen in big rapakivi massifs may be absent in small plutons.

Typical for big massifs is the existence of numerous xenoliths of country rocks in their peripheral part. This phenomenon has been described in detail with reference to the Wiborg massif (Simonen, 1987, p. 9) and his satellite Suomenniemi batholite (Rämö, 1991). The rocks of phase II of the Märjamaa pluton, the biggest pluton in North Estonia, differ from other plutons first of all in regard to their heterogeneity - they may be influenced in places by xenoliths of surrounding rocks. At the same time the relative homogeneity of small potassium granite massifs refers to the probability that assimilated xenoliths play clearly a less important role here than in bigger massifs.

It is supposed that the crystallization temperature of the Wiborg rapakivi pluton was more than $800^{\circ} \mathrm{C}$ (Vorma, 1972). According to Velikoslavinsky and coworkers (Великославинский et al., 1978), the crystallization temperature interval for the granitoid phases of rapakivi is $800-$ $500^{\circ} \mathrm{C}$. Our earlier estimation (using Buddington's and Barth's geothermometers) gives the crystallization temperature for the Märjamaa massif as $650-550^{\circ} \mathrm{C}$.

The $\mathrm{Al}$ content of amphiboles serves as the basis for estimating another parameter of crystallization-pressure (Hammarstrom \& Zen, 1986; Hollister et al., 1987). According to the composition of the amphiboles of the Märjamaa pluton (Table 3 ) the pressure was in the interval of $5.2-6.5$ kbar. It is interesting to note that the same level of pressure $(P=5-6$ 
kbar) has been estimated for the metamorphic rocks of the West-Estonian block surrounding the Märjamaa pluton (Пyypa et al., 1983). Such proposed PT conditions of crystallization of the Märjamaa pluton correspond to the conditions of amphibolitic facies. The chemical composition of biotites and amphiboles (Fig. $3 e-3 f$ ) refers to the same conditions.

New zircon age determinations using the $\mathrm{U}-\mathrm{Pb}$ method gave the result $1.626 \mathrm{Ga}$ (Kirs et al., 1991). The isotopic age of biotites from all Estonian potassium granite plutons determined by the $\mathrm{K}$ - $\mathrm{Ar}$ method is 1.65-1.62 Ga (Пуура, 1974). If the estimation of the crystallization temperature of Märjamaa granite $\left(\max .650^{\circ} \mathrm{C}\right)$ is valid, it follows that the cooling of the pluton down to the temperature of biotite blocking $\left(300^{\circ} \mathrm{C}\right)$ occurred very quickly: during an interval not revealed by usual determination methods.

Attempts have been made to restore the cooling process in small zonal granodioritic plutons on the ground of the $\mathrm{K}-\mathrm{Ar}$ ratio in the minerals of Spider Lake Granite and Chain of Ponds plutons, located on the Canadian Shield west from Quebec (Heizler et al., 1988). On the ground of changes in the composition of $\mathrm{Hbl}, \mathrm{Bi}, \mathrm{Ksp}$ (Or and $\mathrm{Mi}$ ) in the interval of $550-150^{\circ} \mathrm{C}$, the whole estimated cooling process continued for $60 \mathrm{mil}-$ lion years, but the temperature drop from 550 to $350^{\circ} \mathrm{C}$ (until the blockage of biotite) lasted only 4 million years. Similarly, the small plutons of North Estonia are supposed to have been able to keep a rather steep cooling curve till $300-350^{\circ} \mathrm{C}$ with less rapid cooling afterwards. At the time of cooling to $350^{\circ} \mathrm{C}$, a fresh potash feldspar appeared in the surrounding gneiss (Taebla pluton, drill core F 348 ). This explains also, at least partially, the relative heterogeneity of the massifs, the xenoliths in these, and sharp contacts between granites and surrounding rocks.

The distribution of accessories and the peculiarities of zircon generations in a possible xenolith (drill core F 305), in aplite (F 319), and in near-contact granites (F 314, F 348) are also proofs of a considerable heterogeneity and multistage formation process of small potassium granite plutons. Using the morphological criteria worked out for the granites of the Ukrainian Shield (Робул, 1989), the following genesis of the zircons in the North Estonian potassium granites can be proposed:

(1) zircons from phases I and II of the Märjamaa massif are evidently early magmatic;

(2) zircons from the Taebla massif and from phase III of the Märjamaa massif are late magmatic with subhedral cores of early magmatic origin;

(3) intergrown crystals of zircon in granite-aplite (F 319) and partially in leucocratic granites of Taebla are very similar to the zircons of the pneumatolytic stage from the Korosten rapakivi pluton.

All the material presented here strengthens the conviction that the North Estonian plutons have had, regardless of their modest size, a clearly multistage evolution, similar to that of big rapakivi plutons.

\section{REFERENCES}

Hammarstrom, J. M., Zen, E-an. 1986. Aluminum in hornblende: An empirical igneous geobarometer. - Am. Mineralogist, 71, 1297-1313.

Heizler, M. T., Lux, D. R., Decker, E. R. 1988. The age and cooling history of the Chain of Ponds and Big Island Pond plutons and the Spider Lake Granite, west-central Maine and Quebec. - Am. J, Sci., 288, 925—952, 
Hollister, L. S., Grissom, G. S., Peters, E. K., Stoweil, H. H., Sisson, V. B. 1987. Confirmation of the empirical correlation of $\mathrm{Al}$ in hornblende with pressure of solidification of calk-alkaline plutons. - Am. Mineralogist, 72, 231-239.

Kirs, J., Huhma, H., Haapala, I. 1991. Petrological-chemical features and age of Estonian postorogenic potassium granites. - In: Symposium of Rapakivi Granites and Related Rocks. Abstracts, Espoo, 28-29.

Rämö, O. T. 1991. Petrogenesis of the Proterozoic rapakivi granites and related basic rocks of southeastern Fennoscandia: $\mathrm{Nb}$ and $\mathrm{Pb}$ isotopic and general geochemical constraints. - Geol. Surv. Finl., Bull, 355.

Simonen, A. 1987. Kaakkois-Suomen rapakivimassiivin kartta-alueiden kallioperä. Kallioperäkarttojen selitykset, lehdet $3023+3014,3024,3041,3042,3044,3113$, 3131,3133 . Suomen geologinen kartta 1:100 000 .

Soesoo, A. 1993. Estonian porphyraceous potassium granites: Petrochemical subdivision and petrogenetical interpretation. - Proc. Estonian Acad. Sci. Geol., 42, 3, $97-109$.

Soesoo, A., Niin, M. 1992. Petrographical and petrochemical features of the Estonian Precambrian porphyraceous potassium granites. - Proc. Estonian Acad. Sci. Geol., 41, 3, 93-107.

Streckeisen, A. L. 1974. Classification and nomenclature of igneous rocks. - Geol. Rundschau, 63, 773-786.

Vorma, A. 1972. On the contact aureole of the Wiborg rapakivi granite massif in southeastern Finland. - Geol. Surv. Fin1., Bull. 255.

Березкин В. И. 1977. Метаморфизм нижнего протерозоя Алданского щита. Наука, Новосибирск.

Великославинский Д. А., Биркис А. П., Богатиков О. А., Бухарев В. П., Великославинский С. Д., Гордиенко Л. И., Зинченко О. В., Кивисилла Я. Я., Кирс Ю. Э., Кононов Ю. В., Левицкий Ю. Ф., Нийн М. И., Пуура В. А., Хворов М. И., Шустова Л. Е. 1978. Анортозит-рапакивигранитная формация, Восточно-Европейская платформа. Наука, Ленинград.

Вийдинг Х. 1976. Об интерпретации данных минералогического анализа. - In: Методика и интерпретация результатов минералогических и геохимических исследований. Мокслас, Вильнюс, 53-59.

Другова Г. М., Глебовицкий В. А. 1965. Некоторые закономерности изменения состава граната, биотита, роговой обманки при региональном метаморфизме. - In: Региональный метаморфизм докембрийских формаций СССР. Москва-Ленинград, 33-46.

Кирс Ю., Пуура В., Биркис А., Қивисилла Я., Клейн В., Мотуза Г., Нийн М., Сууроя К. 1990. Новые данные о магматических комплексах фундамента Прибалтики. - In: Геология и геохронология докембрия Восточно-Европейской платформы. Наука, Ленинград, 155-165.

Клейн В., Конса М. 1986. Распределение акцессорных минералов в метаморфических комплексах нижнего протерозоя Северной Эстонии. - Изв. АН ЭССР. Геол., 35, 2, 47-52.

Кууспалу Т. 1975. Граниты рапакиви кристаллического фундамента Эстонии. Уч. зап. Тартуск. ун-та, вып. 359. Тр. по геологии, 76-142.

Пуура В. 1974. К-Аr изотопный возраст пород кристаллического фундамента Северной Прибалтики. - Изв. АН ЭССР. Хим. Геол., 23, 1, 40-49.

Пуура В. А., Вахер Р. М., Клейн В. М., Коппельмаа Х. Я., Нийн М. И., Ванамб В. В., Кирс Ю. Э. 1983. Кристаллический фундамент Эстонии. Наука, Москва.

Робул В. М. 1989. Генерационный анализ акцессорного циркона, - In: Генерационный анализ акцессорного циркона. Москва, 78-93, 


\section{PÖHJA-EESTI ALUSKORRA VÄIKESTE PORFUURILAADSETE KAALIUMGRANIITIDE MINERALOOGIAST}

Vello KLEIN, Mare KONSA, Mati NIIN

Uuritud kivimite mineraalse koostise ning mineraalide keemilise koostise määrangud võimaldavad anda mõningaid hinnanguid mineraalide kristallisatsioonitingimuste kohta ning selgitada ka protsesside arengu võimalikku kiirust. Tsirkooni tüpomorfsed erimid on abiks massiivide varaja hilismagmaliste faaside eristamisel.

\section{О МИНЕРАЛОГИИ МАЛЫХ ПОРФИРОВИДНЫХ КАЛИЕВЫХ ГРАНИТОВ КРИСТАЛЛИЧЕСКОГО ФУНДАМЕНТА СЕВЕРНОЙ ЭСТОНИИ}

Велло КЛЕЙН, Маре КОНСА, Мати НИИН

Изучен минеральный состав породы и определен химический состав минералов, что позволило оценить условия кристаллизации минералов, а также возможную скорость развития этих процессов. Типоморфные разновидности циркона могут быть полезны при выделении в массивах ранне- и позднемагматических фаз. 